\title{
Sucession Planning In Family Business: A Take A Look At A Tourism Business
}

\author{
Billy Arlando Sutandyo \\ Soegijapranata Catholic University \\ billy.arlando@gmail.com \\ Maria Y.D. Hayu Agustini \\ Soegijapranata Catholic University \\ mariaagustini84@yahoo.com
}

\begin{abstract}
Family business is a dominant type of business in Indonesia. However, studies have confirmed that only few of them can sustain longer. Succession has not been in the agenda of most family businesses in Indonesia. This research aims at observing succession process in a family business in order to understand how the process is conducted and how well it is according to Walsh's. The researched family business is a business operating in tourism sector, which is processing succession to the second generation. The research gathered information from the owner and the two children who are the successors. Interview and observation were to gather information and descriptive analytic was applied to describe the process of succession. The results indicate that the succession planning in terms of management succession and ownership succession run relatively well and the desired outcomes can be identified clearly. However, the successors are considered as not yet ready for taking the business. Involving them in the strategic activities can possibly fasten the process to make them being ready.
\end{abstract}

Keywords: management succession, ownership succession, tourism, Walsh's succession planning.

\section{INTRODUCTION}

Family business is a dominant type of business in Indonesia, which contributes 95 percent of the total business (Price Waterhouse Cooper, 2014). The Indonesian Statistics noted that their contribution to the national Gross Domestic Product has been more than 80 percent (Swara Karya, 2007). Considering to this number, family businesses take important role in the national economic growth and thus their sustainability in the business possibly becomes crucial issue. However, studies have confirmed that only few of them can sustain longer. 
Family Firm Institute reported that only 30 percent family businesses can endure until the second generation, 12 percent until the third generation, and 3 percent until the fourth and next generations (Hall, 2008). This indicates that most of family businesses have lower endurance under their next generations. Such condition is possibly due to frail succession process in the business. The predecessor may not prepare the successor well enough so that they are ready for handling the business when they have to carry the baton. The survey by the Jakarta Consulting Group (2014) revealed this. The survey reported that not all family (only about 68 percent) businesses in Indonesia prepare their successors. In other words, succession has not been in the agenda of most family businesses in Indonesia.

Succession is a process of transferring power and leadership from the predecessor to the successor in order to ensure that the business can endure from generation to generation (Aronoff, 2003). Succession can run well if it is planned. Since succession planning is a longterm activity for preparing the successor (Sharma et al., 2001), good succession planning will thus result in good succession process (Leonardo, 2016).

Referring to Walsh (2011), succession process is a set of procedures comprising interrelated factors that create causal relationship. Each relationship must be addressed to make the successor has capabilities and experience to manage the business that currently is run by the predecessor. Walsh's succession process focuses on management succession and ownership succession in which the successor is involved in the operational activities of the business before ownership transition process is conducted.

This research aims at observing process of succession planning in a family business in order to understand how the process is conducted and how well it is according to Walsh's. The research focusses on a family business operating in tourism sector. Tourism is a long life business that everyone needs. Tourism business can thus be a long life business and may be 
needed as long as humans exist. Indonesia is considered as having potencies for developing its tourism sector (Kementrian Pariwisata dan Ekonomi Kreatif, 2020). Because of richness in its natural resources, cultures and supporting infrastructures, Indonesia is one of the countries that is in the world investment prospect. In its strategic plan, the government has vision to develop Indonesia tourism to be more advanced, competitive, and sustainable, and to promote local wisdom. Considering such condition, it is important for companies operating in tourism sector to take the opportunity of growing demand in the tourism.

The research observes a family business conducting succession process to the second generation. It is a business in tourism sector that provides service in national and international trips since its establishment in 2005. Due to the age, the owner prepares her children to be ready for taking the business by involving them into the business activities. The owner recognizes growing on the demand and wants to take the opportunity by sustaining the business for as long as it can.

\section{LITERATURE REVIEW}

\section{Family Business}

Family business is a business that is herited to the next generation in the family and the family manages and control the business (Lorna, 2011). Family members are the owner or major stakeholders of the business and they cooperate each other to grow up the business. More specifically, Aronoff and Ward (1995) stated that it is a family business if there are at least 2 family members who have control over the business's finance.

A family business comprises of three interrelated components: management, ownership, and family (Poza, 2010). Each is a subsystem that affects each other (figure 1). This indicates that family business can be apprehended well as a dynamic social relationship between the three 
subsystems. It is a family business if (1) family member(s) have active and strategic position in the business and part of the stockholders; (2) family member(s) are the stockholders; (3) there are stockholders other than the family members who are active in managerial activities of the business; (4) family member(s) who are active and have managerial position in the business but are not the stockholders; (5) there are stockholders other than the family members and are not in managerial position of the business; (6) family member(s) are not the stockholder and do not have managerial position in the business; and (7) persons holding managerial position in the business but are not the family members and the stockholders.

Based on the components, a family business can be in the form of a family owned enterprise (FOE) or family business enterprise (FBE) (Susanto, 2007). The first one is a family business in which the business is owned by a family but is managed by professionals and experts recruited form outside the family members (no family members involve actively in the operational of the business). In the second one, the business is managed and controlled by family members of the founder. All executive positions are hold by the family members.

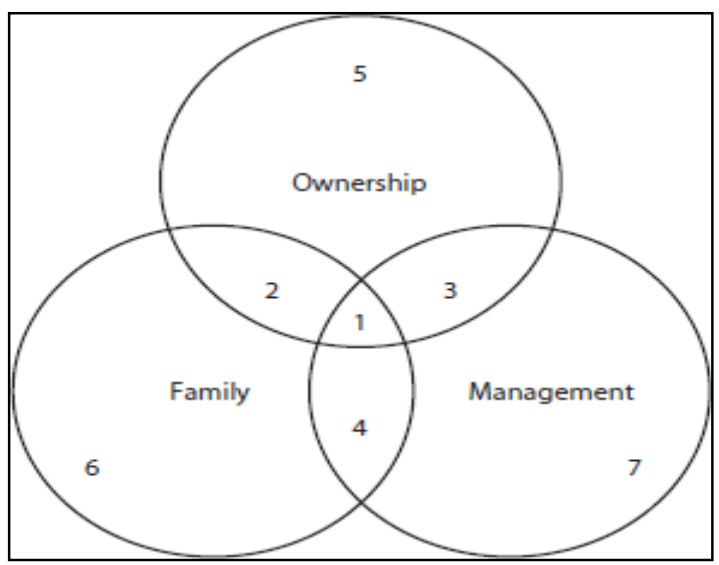

Figure 1. Inner Circle of Business

Source: Poza (2010) 


\section{Succession Planning}

Succession is not the only factor determining success of a family business, but it is certainly that the estafet stick must be handed over to the next generation for the business sustains for long terms. In other words, succession relates to generation transition planning that is systematical and planned by the current owner to the successor. Referring to Walsh (2011), the transition is not always in the terms of leadership but also positions in the managerial layers, it is not only transition of ownership including assets owned by the family but also managerial including policies influencing the business sustainability that must be executed by the successor (Leonardo, 2016) .

Leonardo (2016) stated that succession is vulnerable process since it may have potential failures in its execution. Thus, succession must be planed for it can be successfully implemented. However, succession planning is not as simple as the process of baton pass and not a sudden process in transmitting leadership and managerial control over the next generation. The process itself must be systematical steps and conducted carefully and thoroughly so it can increase quality of the successor, can select the best successor, and can guide the successor to the leadership and managerial transition process.

Succession planning comprises two parts: management succession and ownership succession (Walsh, 2011). Even though they can be conducted at the same time, Walsh recommended to conduct management succession first before ownership succession. This way, the successor has something in mind and plans in supporting managerial activities once he enters the ownership succession process.

Succession activities cover those in the processes of both management succession and ownership succession aimed at integrating family members in the process and in making consensus and succession planning of both processes. The main goal of these is to ensure that 
each family member has clear information about the decision on the ownership of the business and future goals by having policies and process regarding to the succession.

In the process of management succession, the successor is brought to involve in the operational and managerial activities of the business so that he/she can have real experience needed to be in strategic position in the business. There are three main activities that must be carried on in the process: family communication, successor preparation, and management process.

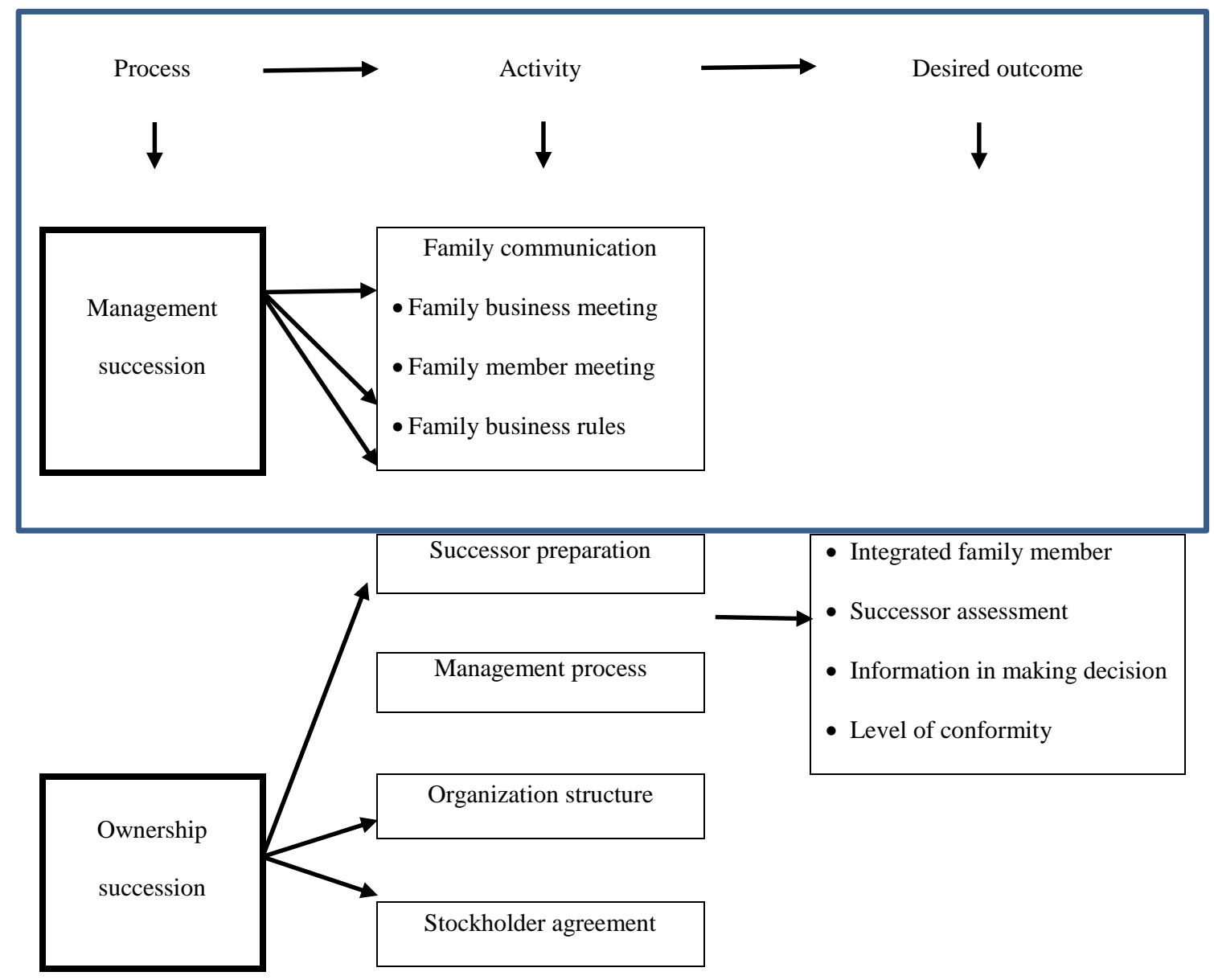

Figure 2. Walsh's Family Business Succession Planning

Source: Walsh (2011) 
Family communication covers policy and meetings conducted in the business. They can be family business meeting inviting only family members who are involved in the business. This meeting is only for active family member and is intended to create interaction between family members and the business in relation to the succession. The meeting can also be family member meeting attended by all family members for them to learn about the business and to give them opportunity to express their opinions on family issues that can influence the business or business issues that may influence the family. Another type of communication is family business rules. They function as guidance for the family members regarding to personal, business, and family relationships. All family members are expected to obey the rules so that potential conflicts that may harm relationships can be minimized. As Tjandra (2018) revealed from his study that family meetings are able to give the successor knowledge not only from the predecessor but also form the other family members.

Successor preparation is to sharpen and train managerial competence of the successor by involving him/her directly in the business activities. The successor is given direct experience in dealing with real problems in the business under the supervision of the current owner. By doing this, he/she can develop suitable managerial characteristics for managing the family business.

Management process is conducted to ensure that management activities reach the desire outcomes. The management must articulate clearly the direction where the business will go and how to reach there. Strategies and action plans developed with consensus can give clear direction, goal, and expectation to everyone. Everyone is expected to understand this and contributes their best to it. This way enables them to focus on their jobs and are motivated to reach their personal and work goals.

In the ownership succession, preparation and ownership or leadership transition from 
the current owner to the successor takes place. Here, family communication in the form of family business meetings, family member meetings, and family business rules still plays important roles as the communication media and collective decision making among the family members regarding to the ownership.

Organization structure plays role in managing the structure of the business in which the family members involve. The structure may refers to Board of Director (BOD) that control operational of the business and make daily decisions, Board of Commissioner (BOC) that acts in supervising business performance, giving advices, but not making decisions, dan Committee of the Board that acts in providing reports for BOC in making decisions. The committees can be audit committee, nomination and remuneration committee, risk policy committee dan corporate governance committee.

Stockholder agreement is the most important thing in the succession process. The successor may not be able to be in a strategic position in the business if the stockholders do not give their agreement. This disagreement is possibly because they are unsure with the capability and experience of the successor.

All succession activities must adhere to the desire outcomes. Four outcomes are expected from the activities. The first outcome is integrated family members. This means that family members who are actively involved in the business manage it to reach the determined goals including successful planning succession. The second outcomes relates to successor assessment. Here, the successor is monitored and supervised by the predecessor in his/her participations in the business. The owner assesses and evaluates his/her performance. Information in decision making is the third outcomes. This refers to the condition in which family members who are actively involved in the business know the information in detail and they are involved in making the decisions. The last outcome is conformity level. It refers to 
well-matched of family members who are actively involved in the business and in the succession planning. Every succession planning policy affect the level of conformity all the family members actively in the business. If a member attunes with the policy, his/her conformity level will be higher and he/she will do the policy contentedly. Thus, problems or conflicts that may arise can be eliminated.

Some studies show that application of Walsh's succession model is able to describe succession planning in family businesses well (Tjandra, 2018; Salindry, 2016; Bing, 2015). These studies identified that management succession and ownership succession have been applied by involving the successor in the business for quite long before the business is handed over to them. The studies also put emphasis on the importance of family communication in building skill and knowledge of the successor about the business. Tjandra (2018) even found that the successor can gain knowledge not only from the predecessor but also from the other family members attending meetings in relation to the family communication.

\section{METHODS}

A qualitative approach was undertaken to understand the succession planning of the business. According to the purpose of the study, it is particularly a descriptive research intended to present a picture of the specific details of a situation (Neuman, 2004), which is succession activities conducted by the family business under the research. Succession is crucial for the business concerning the nature of the business.

As it is a business providing service in national and international trips, detail knowledge about the destinations and their conditions is key success for giving good services for the customers. The owner who is currently running the business has to take many trips for this purpose. Her current age has hindered her to take many trips. Since she must manage the 
business more behind the table, trips to get the knowledge on a destination must thus be taken by another person she can trust since they are not only used for technical plan in creating offers combining accommodations, transportations, scheduling, and tour guidance to a destination but also strategic plan that must be able to provide customers' satisfaction by offering affordable, competitive, and unique offers. Successor must thus be trained to do so.

Interview, observation, and documentation were applied to gather the information that is qualitative in its form. Data qualitative is expressed as numbers, visual images, sounds, or objects (Neuman, 2004). The interview was conducted to the owner and her two children (Soegiyono, 2009). List of questions were set according to the Walsh's model of succession process to ensure that there would be no missing information. Prior to the interview, appointment with each informant was set and time and place for the interview were settled. The interview with each informant was conducted separately and it run for approximately 1 hour for each informant. With their agreement the interview was recorded. Observation and documentation were for gathering information on activities in the business that possibly related to the succession process (Soegiyono, 2009), in particularly family business meeting, family member meeting, rules in the business, successor preparation, management process, organization structure, and stockholder agreement.

Information from the interviews were transcribed and then coded with the frame of succession activities in Walsh's model. Similarly information form the observation and documentations were also coded using the same frame so that they can be analyzed simultaneously. The codes were grouped into two: management succession and ownership succession. Description on each was then provided to picturize how each succession was run in the business (Soegiyono, 2012).

Based on the description, interpretation regarding to the results of succession activities 
was generated. The interpretation was to evaluate the activities and their expected outcomes. Four items of Walsh's expected outcomes (integrated family members, successor assessment, information in making decision, and level of conformity) were used as the basis in interpreting the results.

\section{RESULTS AND DISCUSSION}

\section{The Business and the Family}

The business was established based on the owner's experience who had frequent holidays with her friends each year. It was formed as Limited Corporation (perseroan terbatas) and is located in Semarang. In its early years, the business employed only 1 staff and only gave the service to one destination only. As it develops, it currently employs 6 staff and serves trips around Indonesia and Asia.

The owner handles and manages daily operation of the business since inception. Responsibility and decisions are in her control. She has two boys. They are currently pursuing their bachelor degree and have been involved in the business since the last four years. The owner has given them responsibility in the business. The first child was assigned as a tour planner and the second child was responsible for marketing and tour guide. The owner expects her first child as the successor.

\section{Succession Activities}

The succession activities are divided into two: management succession and ownership succession. Each is described below.

\section{Management succession}

In the management succession, the successor is involved in the managerial and operational activities of the business. The owner of the business has to do so in order to ensure 
that the successor has real experience and skills needed for handling strategic roles in the business. Activities in relation to the management succession are described in 3 parts: family communication, successor preparation, and management process.

\section{Family communication}

The informants stated that family business conducts family meeting regularly. About this the owner stated "Yes, we conducts meeting for the main family members with my two children". The two children also stated the same point. The meeting is every Thursday evening after the working hour. The second child stated this by saying "The family business meeting is conducted once a week, every Thursday evening.” The owner gave emphasis by stating “ ... once a week, Thursday evening after the working hour."

According to the owner, the purpose of the meeting is to give insight on the business to the children. As stated by the owner,"The family business meeting is aimed at giving my both children insight on development of the business." In relation to this purpose, agendas of the meeting are development of the business, evaluated the previous projects, and shared information on coming projects. About this, the second child mentioned "The meeting discusses the business and its development and they asked me about problems I encountered in the previous projects."

Besides the family business meeting attended by the active family members (the owner and two children), meeting for all family members is also conducted. As stated by the owner, in this meeting her husband, besides her two children, is involved. The first child mentioned this by categorizing the family members into active and passive member, in which the passive one refers to the owner's husband who is not involved in the business. The owner and the two children stated that this meeting is run once a month in the last week of the month. 
The family member meeting discusses the condition of the family business. Regarding to this, the owner stated "... besides discussing the current situation and condition of the family business, we share our opinions about strategy to develop the business." This is the way to monitor progress of the business's operational activities. Adding to what the owner stated regarding to the purpose of the meeting, the second child emphasized "The meeting is to identify the competition of the business in particularly tourism sector" also "....what steps we must take to face the current competition."

There are definitely rules applied in the family business. About this, the owner stated "Yes, there are rules in the family business that must be run." The second child stressed that the rules must be obeyed. Referring to the first child and the owner, they cover general rules and specific rules. The general one refers to trip budgeting that must be clear and the specific one relates to rules for staff in providing service during the trip to ensure clients satisfy.

\section{Successor Preparation}

Preparation for successors have been conducted by the owner. About this she stated "Yes, I've already involved the successors in the business since they were in the high school." The children agreed with the owner's statement that they have been involved in the operational business since high school and they are treated as real staff by assigning them in a position. The owner mentioned this "As the successors, I involved my both children as tour planner and tour guide". The second child added "I work as a regular staff doing activities as a tour guide."

Besides experience gaining from direct involvement in the business operational, formal education is also provided and become the requirement for the successors. As cited by the owner "the successors must graduate their bachelor", the children also stated the same "I and my brother are required to finish our bachelor degree" before the business is really transferred to them. 
3. Management process

Management process refers to efforts in finding solutions for problems encountered by the business. Consumers' complaints were the problem that occur frequently. They are those relate to hotel facility, taste of the food, and transportation during the trip. The owner and the second child admitted these problems. "Yes, there were complaints from the customers in relation to the service during the trip," said the owner. "The problems that occur frequently were those relate to hotel, food and transportation," added the second child.

To solve these problems, the informants stated that they looked for alternatives for hotel and restaurant and ensured to use only relatively new bus to satisfy customers. In line with the owner's statement, the second child who was in charge as tour guide mentioned "I will find other hotel and restaurant that give better facilities ... for transportation I will ensure to use only new bus."

\section{Ownership succession}

Activities in ownership succession include family communication, organization structure, and stockholder agreement. Each is describe below.

1. Family communication

Besides giving insight to the successors, the family business meeting described above also discussed ownership transition. About this the owner stated "Sure, we conduct meeting for active family member to discuss about this [ownership transition]." However, according to the first child topic about this is not regularly discuss in each meeting. They discussed this as necessary. Similarly, ownership transition is also brought irregularly to family member meeting involving active and passive members.

Regarding to family business rules, there has no clear rules yet about ownership succession. However, the owner stated that ownership is still equally distributed among the 
successors and " .... no particular percentage yet." The second child emphasized that "currently, there is no particular proportion of the responsibility" or each successor.

\section{Organization structure}

The informants approved that the family business has organization structure. The owner illustrated this "Yes, we have organization structure. ... I am the owner dan my two children are respectively tour planner and tour guide." Referring to the owner, the structure is to strengthen and clarify position and responsibility. The children admitted that the structure helps them to understand their position and responsibility in the business owned by the family.

\section{Stockholder agreement}

There is actually no stockholder in this family business, since the business is owned only by the owner. This is stressed by the owner by stating "I myself is the owner and the stockholder of this business." Consequently, only she monitors the progress of the successors. She stated about this "Yes, I monitor every progress of my two children as the successors of this business either directly or indirectly through other staff who have direct interaction with them." The children admitted that their mother monitors their skills, capability, and maturity to know their readiness in running the family business.

Based on the progress, the owner is sure that her children have the capability. As she stated about this, "Based on my observation on their capability and experience up to now, I believe that my both children have capability to continue this family business." Confirming this to the children, they are also sure that they have the capability needed to run the business.

\section{Evaluation on Succession Activities}

This section elaborates the interpretation of the succession activities described above in relation to the expected outcomes. The four expected outcomes are as follows.

1. Integrated family member 
This outcome refers to the condition where the successors comply with all activities in the succession planning so that the succession can reach the desired outcomes. In terms of management succession, it can be seen that the successors have been involved in the business operations for years. Each of them is assigned a position and they know exactly their responsibility and do the job well. They are prepared by involving them in meetings discussing current issues and problems faced by the business including the competition and are asked their opinions about strategies in dealing with the business conditions and competition. They also follow and obey the business rules applied for all employees since they are treated as regular employees similar to other employees.

In terms of ownership succession, they are also involved in discussing the ownership transition in the family meetings. However, there has no yet clear proportion of ownership given to each successor. They are treated equally by the owner according to their position. One indication is their position in the organization structure which is similarly classified as operational level. This way is to train them in managing the business and the owner still want them to keep learning from her. She expects that they are really ready for dealing with any problems when they officially lead the family business.

\section{Successor assessment}

The assessment relates to monitoring the successors' progress in their involvement and roles in the family business. The assessment is conducted by the owner herself. So far, the owner as the only stockholder, believes that the successors are capable for running the business and agrees to pass the baton to them once they are really ready.

\section{Information in making decisions}

This outcome relates to condition in which all active family members know in detail and involved in discussing the decision made by the current owner. Decisions are still made by 
the owner herself. Even though she involved the successor in the meetings but they are not yet involved in making decisions. She thinks that the successors are not yet ready to lead the family business since they have not been long enough to involve in the business and still need to focus on finishing their study.

\section{Level of conformity}

Level of conformity indicates compliance every active family member involving in the succession planning. In more particularly it refers to the conformity of the successors regarding to the policies applied in the succession planning. It can be stated that level of conformity in this family business's succession planning is relatively good since every process in the succession planning is discussed among the family members and is thus transparent.

Level of conformity will lead to the condition whether the appointed successor have full support from other family members. It is however not revealed yet whether this will happen in the case of this family business. The owner expects her first child is the appointed successor, but there is no information on how the second child will react to this expectation. So far, the owner gives the children the same responsibility but not ownership yet.

\section{CONCLUSION AND IMPLICATIONS}

The process indicates that the succession of the family business has conducted management succession relatively well. Following the Walsh' model, family communication, successor preparation, and management process have been clearly conducted. Meanwhile, in the ownership succession, the owner has prepared the successors and monitored their capability progress even though they are not yet considered as ready for taking the business. 
Evaluation the succession planning of the family business shows that the process has produced the desired outcomes. Integrated family member, successor assessment, information in making decisions, dan level of conformity can be identified clearly.

Since the owner think that the successors are not ready yet for leading the business because they have not involved long enough in the business, the owner can emphasis on the quality of involvement rather than on the length of time. It can be done by giving the successors opportunity to involve in more strategic activities such as decision making so they can be ready faster in handling the business. Even though the roles given to the successors in the position as tour plan and tour guide can be directed to be more strategic one rather than operational one by giving them opportunity take trips and create new offers, implement them, and evaluate them under the supervisor of the owner.

In terms of ownership succession, the owner may prepare each child regarding to her expectation on her first child to be the appointed successor so the transition can be run smoothly especially in relation to the reaction of the second child. The owner can start to announce this in the family business meeting and family member meeting and see the reaction of the second child. The issues regarding to the reaction can be discussed in the family meetings for the solution. Along with this, the owner can start to give the first child bigger responsibility in managerial level to prepare the successor for handling the business at the determined time.

Similar to the previous research, the result also support that Walsh's model can help picturize the succession planning in a family business. Future research may also apply the model in identifying succession in family businesses operating in variety sectors and predict the successful of the process. 


\section{REFERENCES}

Arikunto, S., (2007), Prosedur Penelitian Suatu Pendekatan Praktek, Edisi Revisi VI. Jakarta: Rineka Cipta.

Arnoff, C.E., \& Ward, J.L. (1995). Family Business Governance: Maximizing Family and Business Potential. Family Business Series.

Aronoff, C.E., Stephen L.M, John L.W. (2003). Family Business Succession: The Final Test of Greatness. A Family Business Publication.

Bing, Y. (2015). Proses Suksesi Pada Perusahaan Keluarga Toko Rapi Motor. Thesis. Semarang: Universitas Katolik Soegijapranata.

Hall, A. (2008). Professional Management in Family Business: Toward an Extended Understanding. Family Business Review. 21(1). Accessed from https://journals.sagepub.com/doi/10.1111/j.1741-6248.2007.00109.x

Jakarta Consulting Group. (2014). Suksesi Dalam Perusahaan Keluarga. Accessed from http://jakartaconsulting.com/baru/publications/articles/family-business/suksesi-dalamperusahaan-keluarga/

Kementrian Pariwisata dan Ekonomi Kreatif. (2020). Rencana Strategis 2020-2024. Jakarta: Kemenparekraf/Baperekraf. Accessed from https://www.kemenparekraf.go.id/asset_admin/assets/uploads/media/pdf/media_159888 7965_Rencana_strategis_2020-2024.pdf at 27 July 2021.

Leonardo, Y. (2016). Analisis Perencanaan Suksesi Pada Perusahaan Keluarga PD Bintang di Situbondo. AGORA, 4(1). Accessed from https://www.neliti.com/id/publications/36491/analisis-perencanaan-suksesi-padaperusahaan-keluarga-pd-bintang-di-situbondo

Lorna, C. (2011). The Modern Family Business: Relationships, Succession and Transition. UK: Palgrave Macmillan.

Neuman, W.L. (2004). Basics of Social Research: Qualitative and Quantitative Approaches. Boston: Pearson Education, Inc.

Poza, E. J. (2010). Family Business, Third Edition. U.S.A: Cengage Learning Academic Resource Center.

Price Waterhouse Cooper. (2014). Survey Bisnis Keluarga 2014. Indonesia. Accessed from pwc.com/id/en/publications/assets/indonesia-report-family-business-survey-2014.pdf

Salindry, S. (2016). Perencanaan Suksesi Rumah Makan Ayam Penyet Di Semarang. Thesis. Semarang: Universitas Katolik Soegijapranata. Accessed from http://repository.unika.ac.id/13394/ 
Sharma, P., Chrisman, J.J., Pablo, A.L., \& Chua, J.H. (2001). Determinants of Initial Satisfaction with the Succession Process in Family Firms: A Conceptual Model. Entrepreneur Theory and Practice. Accessed from https://journals.sagepub.com/doi/10.1177/104225870102500302

Soegiyono. (2009). Metode Penelitian Kuantitatif, Kualitatif. Bandung: Alfabeta.

Soegiyono. (2012). Memahami Penelitian Kuantitatif, Kualitatif dan R\&D. Bandung: Alfabeta.

Susanto et al. (2007). The Jakarta Consulting Group on Family Business. Jakarta: The Jakarta Consulting Group.

Swara Karya. (2007). Data Perusahaan Keluarga. Swara Karya.

Tjandra, R. (2018). Proses Suksesi Pada Perusahaan CV. Kurniawa Abadi. Thesis. Semarang: Universitas Katolik Soegijapranata. Accessed from http://repository.unika.ac.id/18543/

Walsh, G. (2011). Family Business Succession: Managing the All-Important Family Component. KPMG Enterprise. 